\title{
The Application of Courtyard and Settlement Layouts of the Traditional Diyarbakir Houses to Contemporary Houses: A Case Study on the Analysis of Energy Performance
}

\author{
İdil Ayçam ${ }^{1, *(\mathbb{D}}$, Sevilay Akalp ${ }^{2}$ and Leyla Senem Görgülü ${ }^{1}$ \\ 1 Department of Architecture, Graduate School of Natural and Applied Sciences, Gazi University, \\ Ankara 06570, Turkey; leylasenem.gorgulu@gazi.edu.tr \\ 2 Department of Architecture, Harran University, Şanlıurfa 63300, Turkey; sevilayakalp@gmail.com \\ * Correspondence: iaycam@gazi.edu.tr; Tel.: +90-312-582-3602
}

Received: 31 December 2019; Accepted: 23 January 2020; Published: 27 January 2020

check for updates

\begin{abstract}
Conventional energy use has brought environmental problems such as global warming and accelerated efforts to reduce energy consumption in many areas, particularly in the housing sector. For this purpose, bioclimatic design principles and vernacular architecture parameters have started to be examined in residential buildings nowadays. Thus, the demand for less energy-consuming houses has started to increase. In this study, we aimed to specify the significance of traditional architectural parameters for houses in the hot-dry climatic region of Diyarbakır, Turkey. Within the scope of the study, a case was based on the urban fabric of the traditional houses in Historical Diyarbakir Suriçi-Old Town settlement and the Şilbe Mass Housing Area was discussed. The courtyard types, settlement patterns, and street texture of traditional Diyarbakır houses were modeled by using DesignBuilder energy simulation program for the case study. Annual heating, cooling, and total energy loads were calculated, and their thermal performances were compared. The aim is to create a less energy-consuming and sustainable environment with the adaptation of traditional building form-street texture to today's housing sector. Development of a settlement model, which is based on traditional houses' bioclimatic design for hot-dry region, was intended to be applied in the modern housing sector of Turkey. Moreover, adapting local forms, urban texture, and settlement patterns to today has significant potential for sustainable architecture and energy-efficient buildings. According to this study, the optimum form and layout of traditional houses, which are one of the climate balanced building designs, provide annual energy savings if integrated and designed in today's building construction. As a result of this study, if the passive design alternatives such as building shape, layout, and orientation were developed in the first stage of the design, energy efficient building design would be possible. The study is important for the continuation of traditional sustainable design.
\end{abstract}

Keywords: traditional Diyarbakır houses; courtyard; settlement; Designbuilder simulation; energy performance

\section{Introduction}

The rapid growth of the world's population has led to a significant acceleration in energy demand and consumption, leading to serious environmental problems such as global warming and climate change [1,2]. Industrialization, the instability between humanity and nature, and globalization are important problems in the building sector [3]. In other words, many sectors such as construction, transportation, infrastructure, industry, agriculture have a significant impact on energy consumption and carbon emissions [4]. Among these sectors, the construction sector that has a large energy 
consumption network is responsible for more than $40 \%$ of global energy use and one-third of global greenhouse gas emissions [5]. It is stated that half of the energy consumed in the buildings is used in heating-cooling and air-conditioning ventilation (HVAC) systems to provide climatic comfort [6]. This situation led to different searches in the construction sector to save energy costs. As a result, passive design strategies have been developed to provide climatic comfort in heating, cooling, and ventilation [7]. As a result of these strategies, it is aimed to provide the necessary comfort conditions of the building with minimum energy consumption by designing the building envelope and its thermophysical properties, orientation, form, material, space organization, and many other parameters in an integrated way.

Traditional building settlements in Turkey and structures that make up these settlements have originated in different ways. In other words, the traditional texture was set up using cognitive rules and unwritten organic street pattern [8]. The different space organizations in these building settlements were formed according to climatic conditions. One of these units, courtyard structure form, is a unit that helps to reduce annual energy consumption with passive cooling technique [9]. The courtyard structure form is based on thermal performance, shading, and natural ventilation. Many research studies have been conducted on the climate performance of the courtyard form in order to address the thermal, shading, daylight, and airflow characteristics of low buildings in different climates [10]. The courtyard building form, which provides control of climatic elements such as sun and wind, causes a temperature difference between the inner and outer surface of the building shell. As a result, it was found that while the temperature of the semi-enclosed courtyard form was higher than the outdoor temperature both in winter and at night, it had a lower value compared to the outdoor temperature due to the shadow effect it created during the summer season [11]. Therefore, in the hot-dry climate zone where the hottest season lasts longer than the coldest one, the courtyard structure form appears as a space organization that provides thermal comforts by using the passive air conditioning elements together. When the traditional street texture in the hot arid climatic zones is taken into consideration, the density of the settlement is often encountered. Within the scope of the study, the street texture of the historical city walls of Diyarbakir and the traditional courtyard houses that make up this texture are discussed. In terms of Fathy, settlement texture has two features, respectively, wide courtyards and tight winding streets [12]. The aim of this study is to create a sustainable and less energy-consuming environment by ensuring the integration of traditional building forms and settlement orders, especially in the sector of mass housing into today's housing sector. As the study area, the historical Suriçi-Old Town texture and the closest Şilbe mass housing settlement unit to this region were discussed. The reason for choosing a mass housing settlement unit in addition to the historical urban texture in the scope of the study is that the housing section Housing Development Administration (TOKI) produces numerous houses and when the basalt, which is suitable for the traditional urban fabric, is used in modelling, the wall section is thick and not quite applicable. In the first step of the study, which was carried out in four steps, literature review and field study on traditional Diyarbakır houses and street texture were conducted. In the second step of the study, assumptions were made with reference to the building envelope properties of the houses in the mass housing units closest to the historical street texture by means of DesignBuilder energy simulation program.

As a result of the literature search, heating-cooling load values of the four most commonly used courtyard forms in the traditional housing texture were calculated and optimum courtyard form was determined. After determining the optimum courtyard building form, the heating and cooling loads due to the shadow effect of the structures in the corner and middle parcels were calculated by taking the street widths of the traditional Suriçi-Old Town texture as a reference. In the conclusion part of the study, by evaluating and comparing the results of the analysis, appropriate settlement alternatives have been proposed for low-rise residential settlements in Diyarbakır Turkey. 


\section{Materials and Method Analysis}

\subsection{Characteristics of the Traditional Settlement of Diyarbakır}

The province of Diyarbakir that is located in the southeast part of Turkey (Figure 1) belongs to the hot-dry region in the classification of climates, and in this region the summer seasons last longer than winter seasons as can be seen via Figure $2[13,14]$. In addition, July is the warmest and January is the coldest month. The average air temperature is $27.5^{\circ} \mathrm{C}$ and the average temperature measurements per month are tabulated in Figure 2 [15].

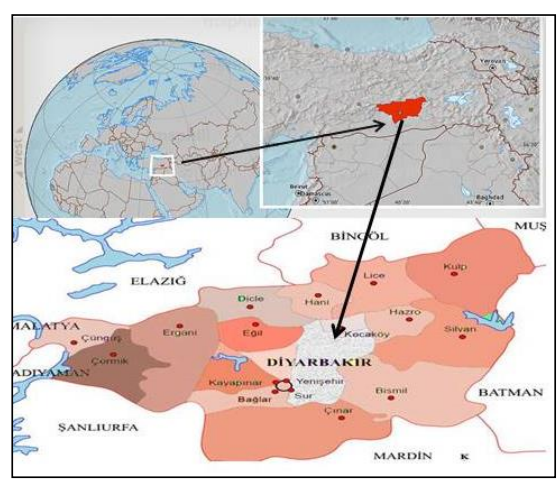

Figure 1. Location of Diyarbakır [15].

\begin{tabular}{|c|c|c|c|c|c|c|c|c|c|c|c|c|}
\hline & January & February & March & April & May & June & July & August & September & October & November & ecember \\
\hline Avg. Temperature $\left({ }^{\circ} \mathrm{C}\right)$ & 22 & 4.1 & 8.3 & 13.7 & 18.6 & 247 & 29.7 & 294 & 24.4 & 17.5 & 10.3 & 4.7 \\
\hline Min. Temperature $\left({ }^{\circ} \mathrm{C}\right)$ & -2.2 & -0.8 & 2.5 & 7.3 & 11.3 & 163 & 21.3 & 20.6 & 15.7 & 9.8 & 4.3 & 0.1 \\
\hline Max Temperature $\left({ }^{\circ} \mathrm{C}\right)$ & 6.6 & 9 & 14.2 & 20.1 & 26 & 332 & 382 & 382 & 33.1 & 252 & 16.4 & 9.3 \\
\hline Avg. Temperature $\left({ }^{\circ} \mathrm{F}\right)$ & 36.0 & 39.4 & 46.9 & 567 & 65.5 & 765 & 85.5 & 849 & 75.9 & 63.5 & 50.5 & 40.5 \\
\hline Min. Temperature ( ${ }^{\circ} \mathrm{F}$ ) & 28.0 & 30.6 & 36.5 & 45.1 & 523 & 613 & 70.3 & 69.1 & 603 & 49.6 & 39.7 & 322 \\
\hline Max Temperature ( $\left.{ }^{\circ} \mathrm{F}\right)$ & 43.9 & 48.2 & 57.6 & 68.2 & 78.8 & 91.8 & 100.8 & 100.8 & 91.6 & 77.4 & 61.5 & 48.7 \\
\hline $\begin{array}{l}\text { Precipitation / Rainfall } \\
\qquad(\mathrm{mm})\end{array}$ & 79 & 71 & 76 & 74 & 46 & 8 & 1 & 0 & 3 & 35 & 59 & 78 \\
\hline
\end{tabular}

Figure 2. The average temperature measurements per month for Diyarbakır [14].

The modelling part of the study is composed of the housing units which are the reference units on the scale of the building envelope and are located in the closest distance to the historical city texture. The Silbe housing estate consists of three stages with different orientations and square meters. The relation with the historical city wall is given in Figure 3.

In this study, we aimed to analyze the effects of climate-based building design features of the historical (Suriçi) residential unit on the energy performance of the building where the traditional residential texture of Diyarbakır is located. In this region, we aimed to give direction regarding climate-based design to find a suitable building form and settlement alternatives for the houses built today. Due to the lack of studies throughout the world and Turkey, this study was designed [16]. 


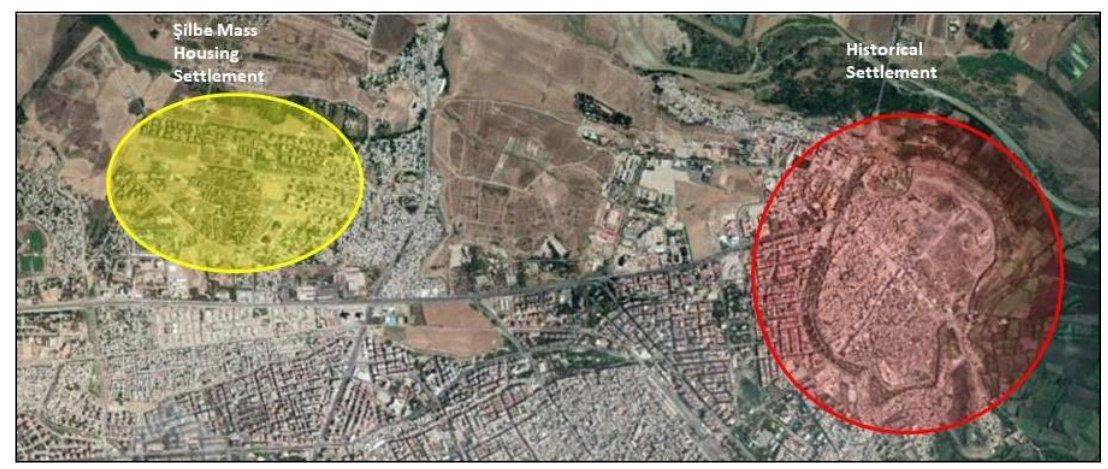

Figure 3. Satellite view of historical Old Town texture-SSilbe collective housing settlement unit $[17,18]$.

Throughout history, the city of Diyarbakır, which has been constantly exposed to war and invasion, has found a solution to build the city with city walls all around. This led to the formation of the urban texture in a limited area. In this urban texture, which is divided as Suriçi-Old Town and new town, urban settlements took place in the inside of the walls until the 19th century; with the rise in the population, to provide the need of housing, new buildings led to adjacent narrow alleys by being built next to already existing buildings. Another important factor in the formation of the historical old town texture walls is the climate. Located in the hot-dry climate zone, this settlement created an organic street texture by being transformed into a courtyard space organization that allows spatial and adjacent articulation to create shaded surfaces, protected from solar radiation [19]. When the traditional houses in the "Sur" city walls are examined, although the parcels in this organic street texture are formally separated from each other, the building masses in the parcel intersect vertically or at an angle close to the vertical. This way, even in the most formally damaged parcel, the building masses intersect almost vertically. Moreover, the parcel areas of traditional Diyarbakır houses vary between 85 and $1000 \mathrm{~m}^{2}$. The areas labeled as the small parcels are $85-100 \mathrm{~m}^{2}$ and the area of big parcels vary between 700 and $1000 \mathrm{~m}^{2}$ [20]. In addition, the size and forms of the parcel are the major factors in the formation of the existing urban texture and an organic form.

The narrow streets of the traditional street texture have made the structure physically cut off some negative environmental factors. In other words, the high walls created a shadow effect in the courtyards. In addition, living in the courtyard brought by the warm-dry climate region as a user requirement has caused some sound reflections. However, the basalt stone, which is used as a traditional building material, absorbs the sounds due to its porous structure [28]. In the adjoining narrow street texture, the spaces are only the courtyard and a small number of gaps [29]. The courtyard has a significant influence on the formal formation of the traditional urban texture. It is seen that there are different courtyard types in the Middle East Region which forms the basis of today's courtyard type space organization. In this region, where hot and dry climatic conditions prevail, it is seen that the places are located on the north-south axis as the zoning makes it difficult to control the east and west sun [30]. For this reason, it is seen that the openings are at minimum dimensions in the spaces facing the north direction and the windows placed in the north-south directions benefit from cross-ventilation [23]. The traditional residential settlements of the province of Diyarbakir also have the characteristics of the traditional residential settlements in the hot dry climate. It is seen that the design principles regarding solar control, passive cooling, and increasing ventilation are benefitted from in these settlements. This situation has had a direct impact on traditional housing orientation and space organization. In other words, the courtyard pattern thermal performance links to two integrally working strategies: protecting buildings from solar radiation and natural ventilation [31,32].

In the traditional Diyarbakır houses, space was organized with the courtyard building unit being the center. In other words, with an inward-looking design, the courtyard is the focal point of the whole house and the other sections are positioned so that they are shaped according to the courtyard. The climate factor comes to the forefront in the orientation of the building masses around the courtyard. 
In hot-dry climatic zones, the fact that the hottest period lasts longer than the coldest period has led to the emergence of a design understanding where measures to reduce solar radiation and to minimize the drying effect of the wind are at the forefront. The most prominent part of traditional Diyarbakır houses is summer spaces in the south wing of the courtyard [20]. Thus, the spaces in the south wing are positioned in the north direction and designed to receive minimal solar radiation during the day. In addition, these units have further importance in terms of the frequency of use. In the building mass directed to the northern wing of the courtyard, the spaces were designed to face south. In houses that do not have a northern wing, the building masses positioned to the east are considered as winter wings. (Table 1). The examples regarding the seasonal orientation of the traditional Diyarbakır houses are depicted through Table 2. In other words, the buildings in this wing are closed or have few transparent surfaces in order not to expose the spaces directed to the south to sunlight too much [34]. Briefly, the spaces in the south of the courtyard and the openings facing the north (courtyard) are planned as summer wings, and the spaces in the north of the courtyard and facing the openings in the south (courtyard) are planned as winter wings which is illustrated in Table 3 [35-40].

Table 1. Examples of space, street pattern in the historical settlement [21-27].

\begin{tabular}{|c|c|c|}
\hline Locati & istorical Settlement & Top View of Settlement \\
\hline Eyvan & $\begin{array}{l}\text { Three sides closed and single arch } \\
\text { opening the courtyard. }\end{array}$ & $\frac{\text { Example of Eyvan }}{\text { minn }}$ \\
\hline Kabalatı & $\begin{array}{l}\text { Vaulted passageways Kabalt } 1 \text { is } \\
\text { enclosed by high walls. Basalt } \\
\text { stone is used as building material } \\
\text { in Kabaltı. }\end{array}$ & Examples of Kabaltı \\
\hline $\begin{array}{l}\text { Street } \\
\text { Width }\end{array}$ & $\begin{array}{l}\text { Street widths vary between } 1.90 \\
\text { and } 2.50 \mathrm{~m} \text {, but it can be seen to } \\
\text { increase up to } 3.00-4.00 \mathrm{~m} \text { widths. }\end{array}$ & $\begin{array}{l}\text { Narrow streets in the traditional } \\
\text { Suriçi pattern }\end{array}$ \\
\hline Rooms & $\begin{array}{l}\text { The height of the summer rooms is } \\
4-5.5 \mathrm{~cm} \text { and the aspect ratio is } 4 \times \\
7-3.5 \times 6 \mathrm{~m} \text {; the height of the } \\
\text { winter rooms varies between } 3 \text { and } \\
3.5 \mathrm{~m} \text { width and } 3 \times 4 \text { and } 2.5 \times 3 \\
\mathrm{~m} \text {. }\end{array}$ & Example of traditional room \\
\hline
\end{tabular}


Table 2. Parts of a typical traditional house in the Diyarbakır old town settlement, Cahit S1tkı Taranc1 house [33].

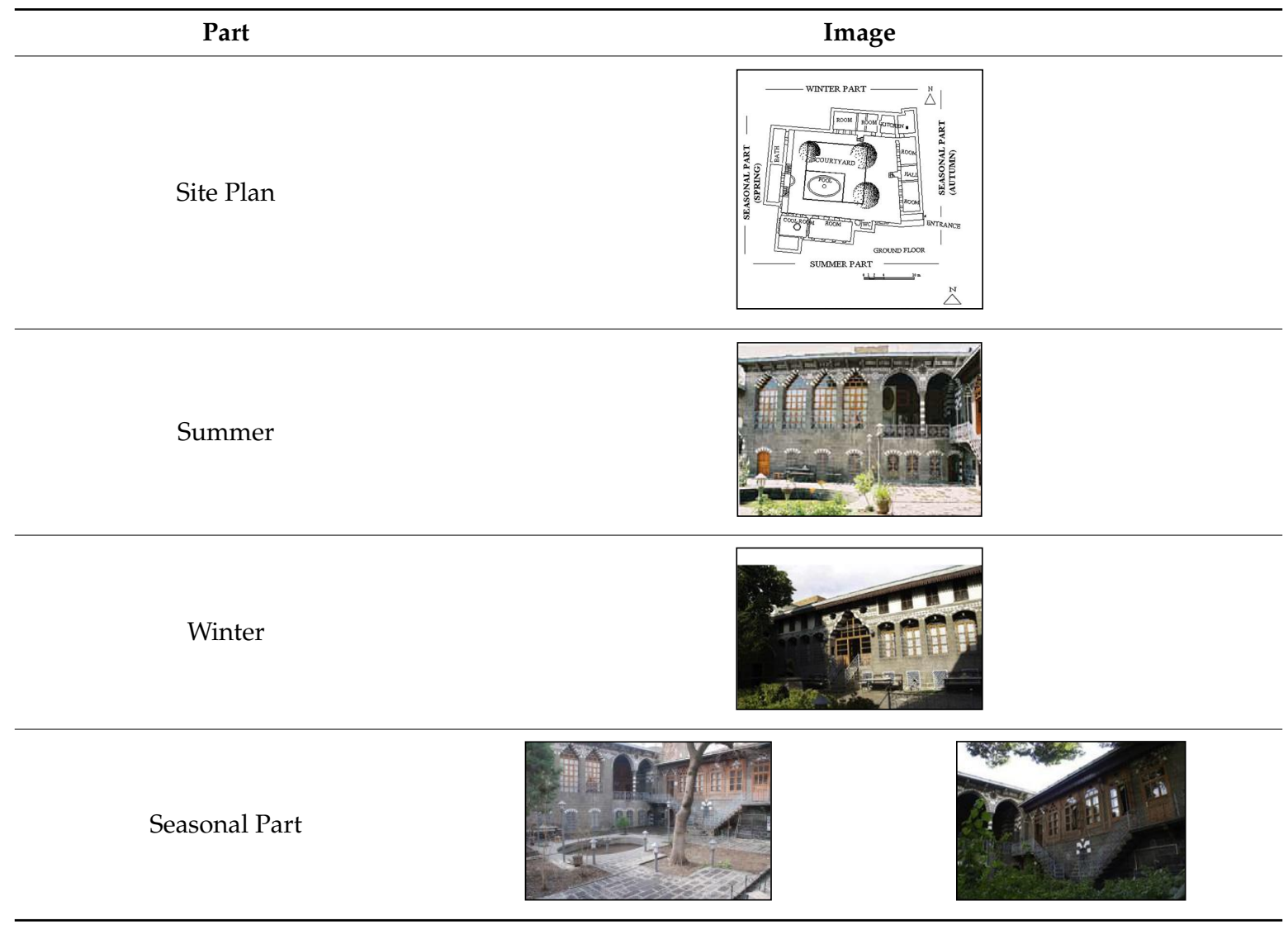

Table 3. The positioning of the seasonal spaces [41].

\begin{tabular}{|c|c|c|}
\hline \begin{tabular}{|l|} 
A \\
\end{tabular} & Part & Orientati \\
\hline & Summer & \multirow{2}{*}{\begin{tabular}{|c|} 
COURTYARD \\
ROOM \\
\end{tabular}} \\
\hline & Room & \\
\hline \multirow{2}{*}{\multicolumn{2}{|c|}{$\begin{array}{l}\text { Winter } \\
\text { Room }\end{array}$}} & \begin{tabular}{|l} 
ROOM \\
\end{tabular} \\
\hline & & CoURTYard \\
\hline & $\begin{array}{l}\text { Spring } \\
\text { Room }\end{array}$ & 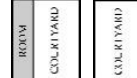 \\
\hline
\end{tabular}

In traditional Diyarbakir houses, the courtyard and the Eyvan have a great influence on the orientation of the other units. The plan typology of traditional Diyarbakir houses is classified as $\mathrm{U}, \mathrm{I}$, and L type according to the wings arranged around the courtyard in the literature [42]. In addition, according to the openings left by the wings around the courtyard, it is possible to rank them as plan types with outer, inner, and middle courtyards. In the L-type plan, the courtyard is surrounded by two adjacent wings. The wing located in the south and whose opening faces north is defined as a summer house. In order to provide privacy in this plan type, exposed areas were separated from the street by high walls. In the U-type plan, all three sides of the courtyard are surrounded by spaces. The biggest advantage of this type of plan is that the wings are positioned as a summer house and winter house in optimum directions, which correspond to the climatic data of Diyarbakir. The U-type plan is the type of residence preferred by families with a high level of economic welfare. In the type I plan, also known as the inner courtyard plan type, the two sides of the courtyard are mutually arranged. The remaining 
sections were covered by walls and entrance doors. In plan type with a central courtyard, all four sides of the courtyard are surrounded by spaces. The courtyard types mentioned above is presented via Table 4. The major advantage of this type of plan is that it will meet the user requirements in four seasons. The most used plan type in the traditional old town texture is the central courtyard type [42].

Table 4. Orientations used according to housing plan types in Diyarbakır [19].

\begin{tabular}{c}
\hline L Type \\
$\begin{array}{c}\text { Outer } \\
\text { Courtyard } \\
\text { Plan }\end{array}$ \\
$\begin{array}{c}\text { Inner } \\
\text { Courtyard } \\
\text { Plan }\end{array}$ \\
$\begin{array}{c}\text { Center } \\
\text { Courtyard } \\
\text { Plan }\end{array}$ \\
\hline Type Type
\end{tabular}

\subsection{Material and Method}

DesignBuilder Energy Simulation program was used in this study. DesignBuilder is a dynamic simulation tool that calculates all building energy, lighting, carbon, and comfort performance analyses [43]. The program is preferred because it has a user-friendly interface and the simulation results are realistic. DesignBuilder simulation program is used in many disciplines because it is reliable software. It can be used actively in architecture, building physics, mechanical engineering, heating and cooling systems modelling. In addition to heating-cooling load modelling, lighting has the ability to calculate daylight and model computational fluid dynamics (CFD) [44].

IWEC (International Weather for Energy Calculations) climate data of the province of Diyarbakır, located in the hot-dry climate region, which was selected as the study area, was introduced to the program. Comfort conditions were determined by making certain constants and assumptions to carry out analyses through the DesignBuilder Energy Simulation Program. Building heating and cooling systems were used as a reference in the mass housing settlements used in the region, the building heating system was introduced as natural gas, and the cooling system was introduced as electric energy to the program. In order to provide climatic comfort, seasonal differentiation was preferred. Furthermore, to provide internal climatic comfort, the indoor air temperature comfort value was set to $21^{\circ} \mathrm{C}$ and the heating-setback setting was set to $16^{\circ} \mathrm{C}$ in winter. For the summer season, the indoor air comfort value was $25^{\circ} \mathrm{C}$ and the cooling setback temperature was $25^{\circ} \mathrm{C}$. In addition, the number of residential users was determined to be four. User activity level 0.9 MET (metabolic equivalent of task) winter garment insulation value was accepted as $1 \mathrm{Clo}$ and summer garment insulation value was accepted as 0.5 Clo.

The residential type was chosen as the construction type. As a floor height, by taking traditional Diyarbakır houses as a reference, a two-storey, 8-m-high summer mass with openings facing north was determined. When it comes to building shell and thermophysical properties, the building shell 
properties of the collective housing buildings in Diyarbakır were taken as reference. The physical model of the building shell of the courtyard is shown in Figure 4. About the optical properties, since the mass facing the courtyard is more important than the main facade in the traditional Diyarbakir houses, the transparency ratio of the surfaces facing the courtyard was determined to be $35 \%$ and the transparency ratio of the facade was $25 \%$. In addition, a single glass of $6 \mathrm{~mm}$ thickness was used as the type of glass (Table 5).

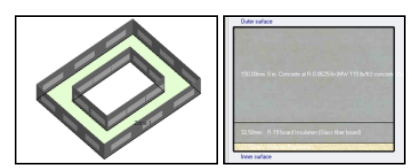

Figure 4. Courtyard and building shell section modeled with DesignBuilder (DB version 5) [45].

Table 5. Building crust and thermophysical properties in investigated houses.

\begin{tabular}{|c|c|c|}
\hline & Properties & U-Value $\left(\mathrm{W} / \mathrm{m}^{2} \mathrm{~K}\right)$ \\
\hline $\begin{array}{l}\text { Reinforced Concrete Exterior } \\
\text { Wall }\end{array}$ & $\begin{array}{l}\text { Reinforced Concrete Precast Wall } \\
\qquad(15 \mathrm{~cm}) \\
\text { Glass Fiber Insulation }(3 \mathrm{~cm}) \\
\text { Gypsum Plastering }(1.25 \mathrm{~cm})\end{array}$ & 0.814 \\
\hline Tilling on the Floor & $\begin{array}{c}\text { Terrazzo Tile }(3 \mathrm{~cm}) \\
\text { Levelling Concrete }(4 \mathrm{~cm}) \\
\text { Blind Concrete }(10 \mathrm{~cm}) \\
\text { Clinker Filling }(20 \mathrm{~cm}) \\
\text { Concrete Fundament }(60 \mathrm{~cm}) \\
\text { Insulation }(3 \mathrm{~mm})\end{array}$ & 0.545 \\
\hline The Ceiling Dividing the Garret & $\begin{array}{c}\text { Bitumen Sheet }(2 \mathrm{~mm}) \\
\text { Heat Insulation }(2 \mathrm{~cm}) \\
\text { Bitumen Sheet }(2 \mathrm{~mm}) \\
\text { Reinforced Concrete Wall }(15 \mathrm{~cm})\end{array}$ & 0.466 \\
\hline
\end{tabular}

The study was carried out in two stages. In Step 1, a summer mass placed in south with two rooms, a size of $4 \times 12 \mathrm{~m}^{2}$ and two floors, height of $8 \mathrm{~m}$ was determined based on the room sizes in traditional Diyarbakır houses and in the masses with again the same size and height called adiabatic which does not provide any heat exchange with its environment while only providing a shadow effect, $8 \mathrm{~m}$ wide courtyard structure forms with L, U, central, and inner courtyards were created (Table 6). The reason why adiabatic mass was preferred in the study is that free convection heat transfer from a horizontal, isothermal fin attached cylinder placed between two nearly adiabatic walls has various applications in industry [46]. Then, the heating and cooling loads due to the shadow effect of the most commonly used forms in traditional Diyarbakır houses were compared and the optimum building form was determined. 
Table 6. Courtyard alternatives by using adiabatic building mass.

Courtyard Alternatives by Using Adiabatic Building Mass

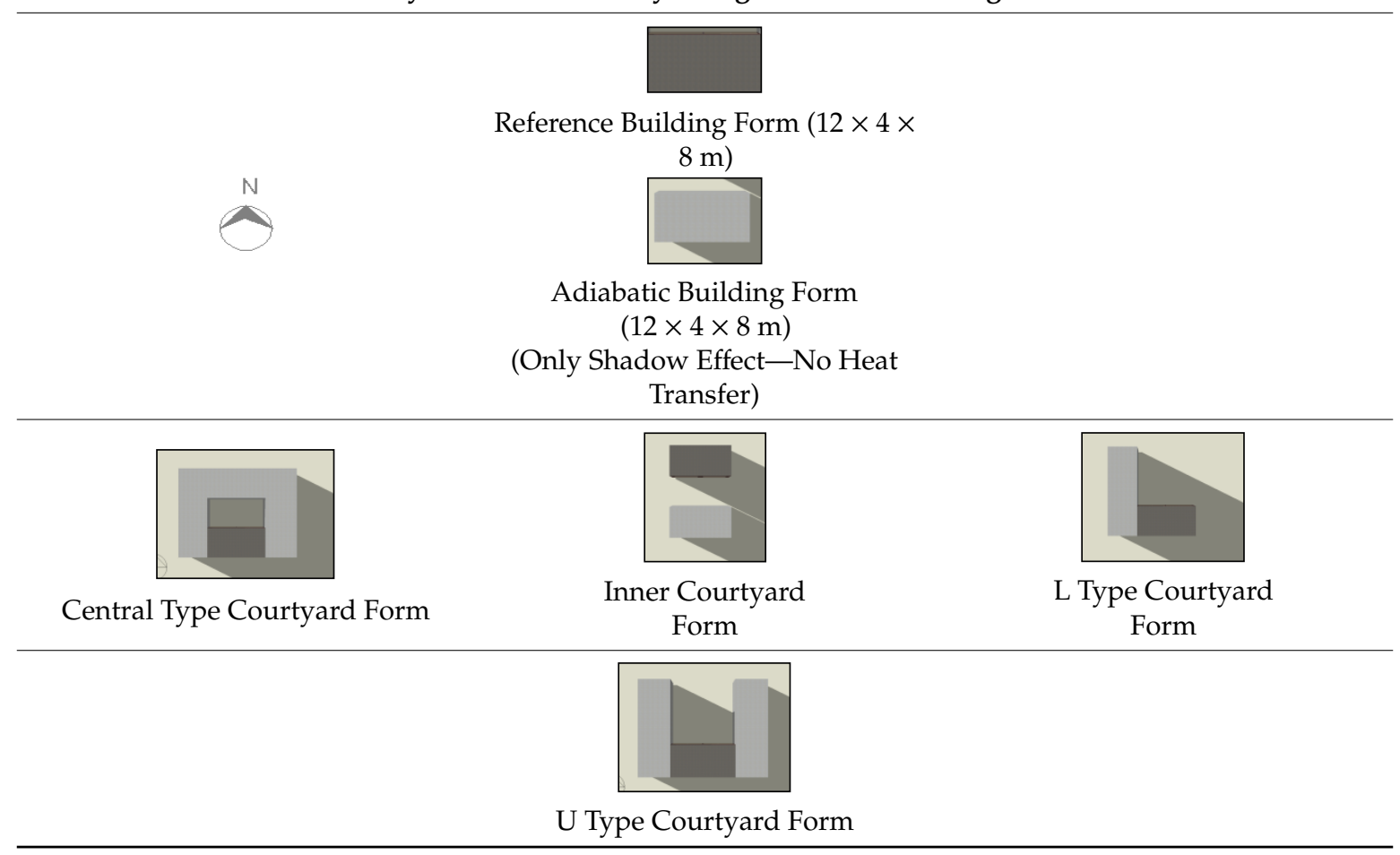

In the second step of the study, heating-cooling loads due to the shadow effect of different street widths and orientations were analyzed with reference to the $20 \mathrm{~m}$ wide, $16 \mathrm{~m}$ long, and $8 \mathrm{~m}$ high central courtyard building form (Figure 5). In other words, due to the shadow effect created, the thermal performances of the referenced central courtyard structure form with 3-6 $\mathrm{m}$ wide adiabatic building masses in different settlements were analyzed to determine the optimum type of street texture (Table 7).

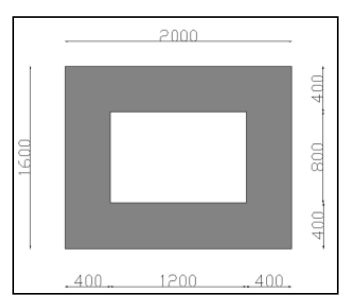

Figure 5. Reference courtyard form and dimensions (m). 
Table 7. Different settlement layouts with streets with widths of 3 and $6 \mathrm{~m}$.

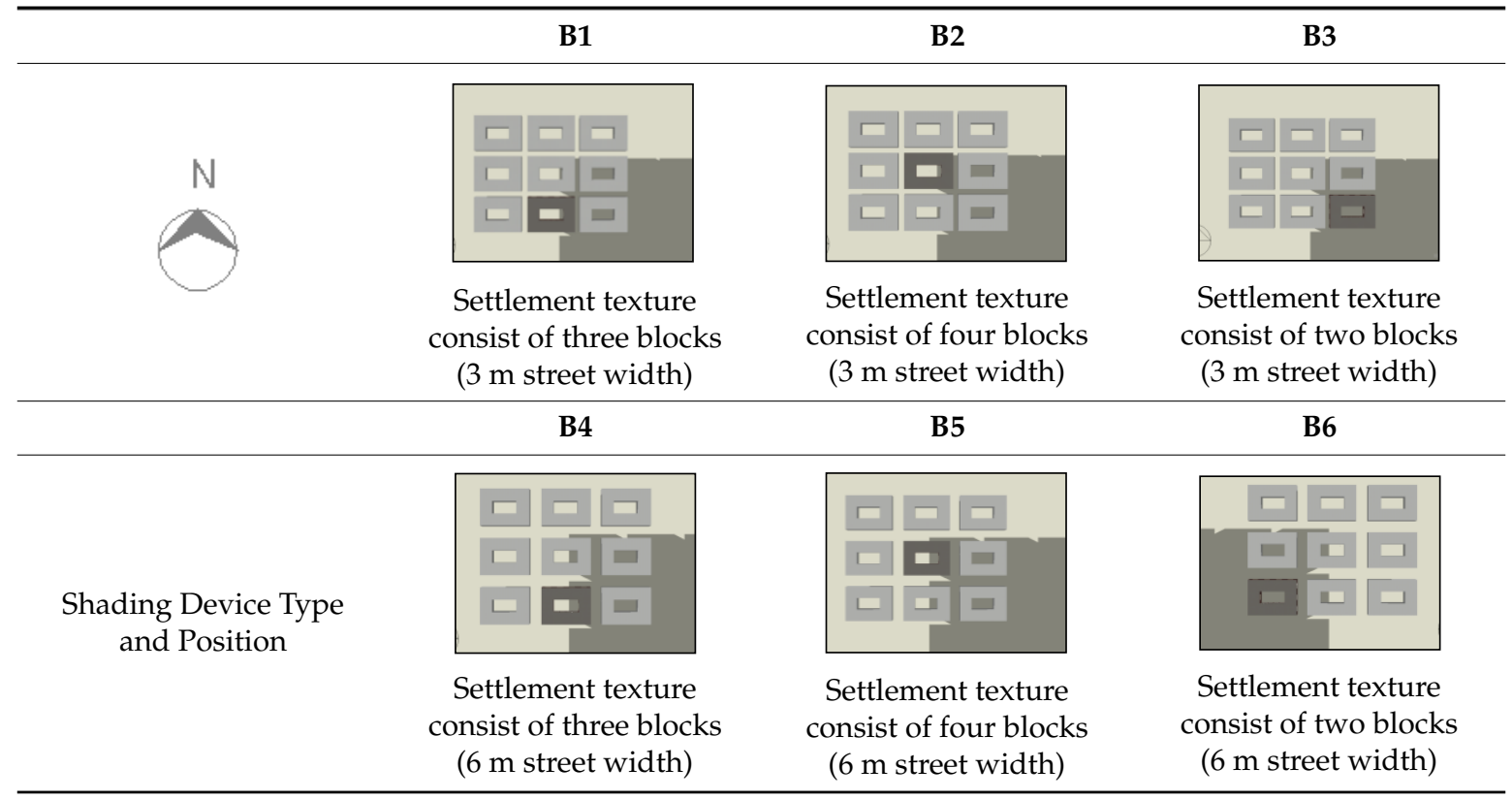

\subsection{Analysis of Simulation}

The courtyard building forms, which are frequently used in traditional Diyarbakır houses, were formed by adiabatic masses. In Diyarbakır, which is located in the hot-dry climate region, it was determined that the annual cooling load expenses are higher than the heating load expenses in all forms of construction. For this reason, it was obtained as a result of the analysis that the annual cooling load in the middle courtyard plan type decreased compared to the reference building. Moreover, when the examined building forms were examined, it was found that the cooling load expenses due to the shadow effect reduced. In addition, the building form that would minimize the total cooling load per year was found to be the plan type with a central courtyard. When total annual heating load expenses are compared, annual heating loads increase in inner courtyard building form, while other building forms decrease in values compared to the reference building. As a result of the analysis, it was determined that the optimal structural form was the central courtyard plan type among the heating load values, and also the L type courtyard type had similar values. When the total yearly heating and cooling load values are compared with the reference building, in other words, when the reference building which is not exposed to any shadow effect and the shadow forms with adiabatic building masses are compared, it is found that the optimum form regarding energy performance is the central courtyard building type (Figure 6).

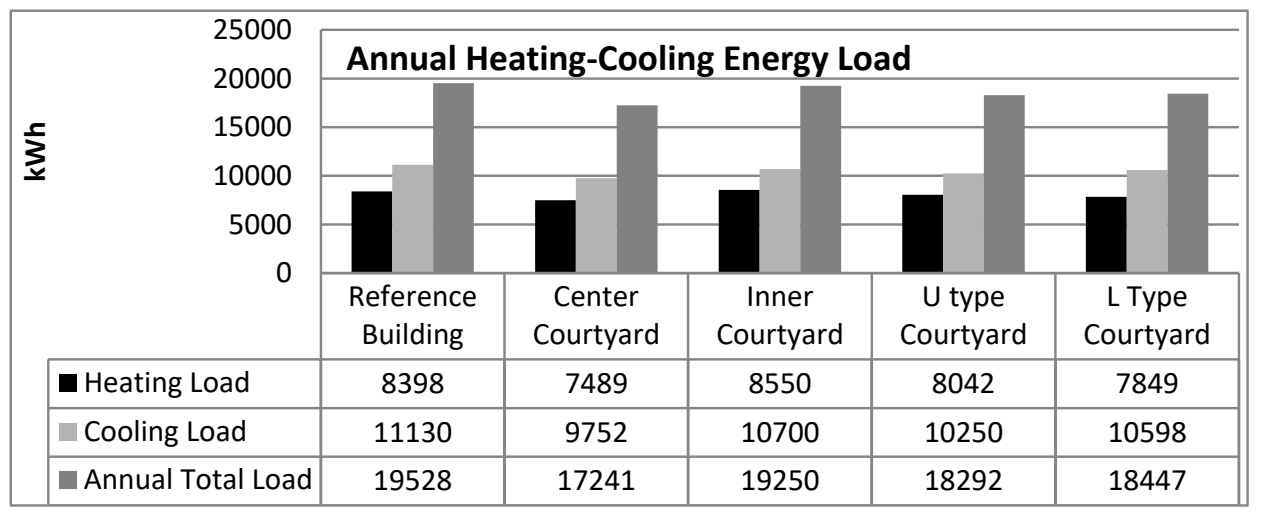

Figure 6. The effect of change of courtyard form on heating-cooling load values. 
The plan of the central courtyard, which was previously determined as the optimum building form, was selected and the annual cooling-heating load values of different street widths and settlements were compared. In other words, the reference building form with the central courtyard, which is not surrounded by any building mass, was compared with the annual heating-cooling load values due to the shadow effect of the building island with a different layout. In the first stage, the street widths were fixed everywhere, $3 \mathrm{~m}$ as accepted, and three different settlements were compared with the reference building. The effect of annual heating-cooling load values on heat gain and losses due to shadow effect of the B3 corner parcel surrounded by the structures on two sides, middle parcel B1 surrounded by the structures on three sides, and B2 inner middle parcel surrounded by the structures on four sides were examined. As a result of the analyses, if the cooling loads connected to the B1, B2, B3 layout are compared, the optimal layout is determined as B2 layout surrounded by the structure on four sides provided that street widths are kept constant everywhere. When the heating loads due to the shade effect of the settlement layout were compared, it was found that the shade effect had a negative effect on energy costs. In other words, an increase in the heating loads due to the shadow effect was observed in all three settlements. However, B2 layout was determined as the layout with the highest heating load value due to the shadow effect on the four sides.

When the total annual heating and cooling load values are compared with the reference building (Figure 7), the optimal layout is determined as the B1 layout, which is surrounded by structures on three sides. In order to examine the effect of the same settlement on different street widths, the settlement islands of B4, surrounded by the buildings on three sides, B5 surrounded by the buildings on four sides and B6, which is a corner parcel surrounded by the buildings, were created. When the annual cooling load values of the B6 corner parcel surrounded by two sides structure, B4 middle parcel surrounded by three sides structure and B5 inner middle parcel layouts surrounded by four sides structure are compared, the optimal layout is determined to be B5 settlement layout surrounded by four sides structures. In other words, it was determined that the cooling load values of the settlement arrangement B5 having the maximum shade effect had the least value. When the heating loads were compared, it was found that annual heating loads increased in all settlements, but this increase was less than other combinations in the corner parcel B6 settlement layout, which was surrounded by the structures on both sides. It was determined that the settlement with the highest increase in annual heating loads was the B5 settlement plan surrounded by structures on four sides which was exposed to the maximum shade effect. When the total annual heating-cooling load values of different settlements connected to the street texture with a width of $6 \mathrm{~m}$ are compared, it is found that optimal settlements are B6 settlement layout surrounded by the structures on both sides.

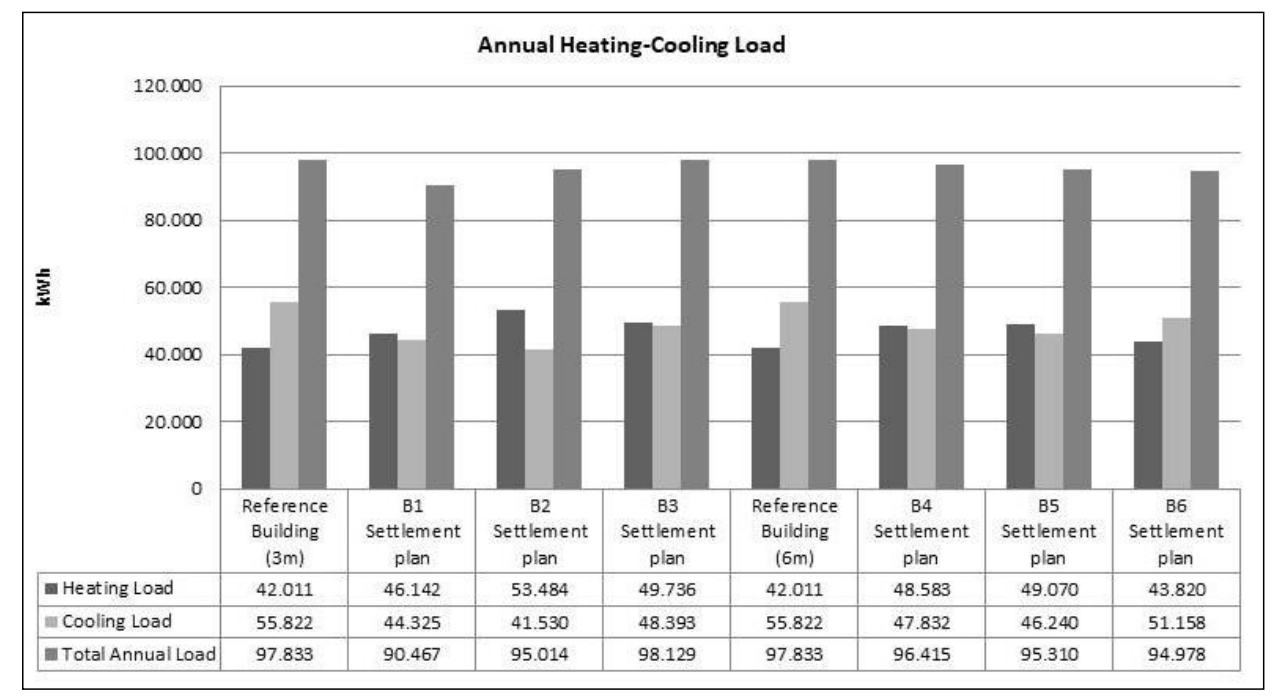

Figure 7. The effect of change of courtyard form on heating-cooling load values. 


\section{Results}

As a result of the analyses performed through the Design-Builder energy simulation program, changes in the annual heating-cooling load values of the building form and street texture were determined. The mentioned results are examined under the following headings:

\subsection{Annual Energy Gain-Loss Changes of Building Form}

The heating-cooling energy gains and losses of different building forms formed with the reference structure and adiabatic masses were compared. As a result of the analyses, it is seen that the plan type with the central courtyard has a gain of $12 \%$ cooling and $14 \%$ heating load annually compared to the reference building. In other words, plan type with a central courtyard was determined as the most efficient form of energy compared to other building forms. When other building forms are examined, it is seen that the cooling load in $\mathrm{U}$ courtyard type has increased by $4 \%$ and in $\mathrm{L}$ courtyard form by $6 \%$. However, in the inner courtyard plan type, cooling loads increase by $2 \%$ due to insufficient shadow effect. When the four building forms are considered, it is seen that the shadow effect has a decisive effect on the cooling loads for the province of Diyarbakır, where there is a hot-dry climate. Again, when comparing the annual heating load losses and gains of the reference building with different buildings' forms, it was found that $14 \%$ of the annual gain was achieved in the plan type of the central courtyard. Among other building forms, it was determined that the building form, which has the minimum gain among the annual heating load values, was the inner courtyard plan type.

Based on the total heating-cooling load values of the reference building, the annual total heating-cooling load percentage gains of other building forms were calculated, and it was determined that the plan type with the central courtyard among these building forms was the optimum building form. This building form is followed by U courtyard type with $7 \%$ and $\mathrm{L}$ courtyard type with $6 \%$. It is determined that the inner courtyard plan type does not provide significant gains for the hot-dry climate zone in terms of energy costs, in other words, it is a form of low adaptation form for this climate zone. Furthermore, when Table 8 is examined, it is found that although the shading effect and cooling load values are more important than other parameters in the hot-dry climate zone, heating loads as well have great importance on annual gains in comparison of total heating-cooling load values.

Table 8. Annual energy gain-loss change percentages of building form.

\begin{tabular}{cccc}
\hline Street Pattern & $\begin{array}{c}\text { Cooling Load Exchange } \\
\mathbf{( \% )}\end{array}$ & $\begin{array}{c}\text { Heating Load Exchange } \\
\mathbf{( \% )}\end{array}$ & $\begin{array}{c}\text { Annual Total } \\
\text { Heating-Cooling Load } \\
\text { Exchange (\%) }\end{array}$ \\
\hline Center Courtyard & +12 & +14 & 13 \\
Inner Courtyard & -2 & +4 & 1 \\
U type Courtyard & +4 & +8 & 7 \\
L type Courtyard & +6 & +5 & 6 \\
\hline
\end{tabular}

\subsection{Annual Energy Gain-Loss Percentages due to the Shadow Effect of the Different Settlement Layouts}

The heating-cooling load gain percentages are given due to the shade effect of different layouts and street widths. The annual cooling load gains of different settlements surrounded by three sides (B1), four sides (B2), and two sides (B3) buildings with a street width of $3 \mathrm{~m}$ are given in the table. Among the alternative settlements, it was found that the B2 settlement, which was most exposed to shade effect and surrounded by building masses on all four sides, had the highest cooling load gain with a rate of $34 \%$. It is determined that the B1 settlement which is surrounded by structures on three sides saves $25 \%$ and the B3 settlement which is surrounded by structures on two sides saves $15 \%$ cooling loads (Table 9). When the reference building and annual heating load values are compared, heat losses were determined in alternatives including all settlements. However, among the total annual heating expenses, the highest loss was found in the B3 settlement which is surrounded by the structures 
on two sides and corner parcel. Among the alternatives with a street width of $3 \mathrm{~m}$, the total annual heating-cooling energy gains were determined in the B1 settlement plan surrounded by the buildings on three sides, while it was found there was no significant difference between the B3 settlement plan surrounded by the buildings on the two sides and the reference building. In other words, there is no significant difference in terms of annual energy loss-gains between the reference building on a single building scale and the settlement plan B3, which is surrounded by buildings on both sides. In the case where the street width is fixed everywhere and $6 \mathrm{~m}$, it is determined that the settlement plan which shows a gain in the annual cooling load values is the B4 settlement which is surrounded on three sides. The B6 settlement plan in the corner parcel was the least profitable among the alternatives.

Table 9. Annual energy gain-loss percentage changes due to shadow effect of different settlement layouts.

\begin{tabular}{cccc}
\hline Street Pattern & $\begin{array}{c}\text { Cooling Load Exchange } \\
\mathbf{( \% )}\end{array}$ & $\begin{array}{c}\text { Heating Load Exchange } \\
\mathbf{( \% )}\end{array}$ & $\begin{array}{c}\text { Annual } \\
\text { TotalHeating-Cooling } \\
\text { Load Exchange (\%) }\end{array}$ \\
\hline B1 Settlement Plan & +25 & -9 & 8 \\
B2 Settlement Plan & +34 & -11 & 3 \\
B3 Settlement Plan & +15 & -16 & 0.3 \\
B4 Settlement Plan & +17 & -14 & 1 \\
B5 Settlement Plan & +13 & -14 & 4 \\
B6 Settlement Plan & +10 & -4 & 4 \\
\hline
\end{tabular}

When annual heating loads were compared, heat losses due to shadow effect were observed among all alternatives. Among these heat losses, the alternative having the least value was found to be the corner parcel B6 settlement layout surrounded by the structures on both sides. It was determined that the heating load losses of the B5, surrounded by the structures on all four sides and B4 buildings, surrounded by the structures on three sides were equal. When the total annual heating and cooling energy gains were compared, it was determined that the optimal alternative with a width of $6 \mathrm{~m}$ street was the B5 settlement layout surrounded by the structures on four sides and the corner parcel B6 surrounded by the structures on two sides. If the reference building and six different layout plans are compared together, the B1 settlement layout, which is surrounded by three-side buildings with a street width of $3 \mathrm{~m}$, was identified as the building island that uses energy in the most efficient way. In addition, if the street width was increased, an increase in the cooling loads due to the decrease in shade effect was observed in alternatives with the same layout (B2-B5, B1-B4, B3-B6). The B1 alternative, which is surrounded by structures on three sides with an optimal layout of $3 \mathrm{~m}$ of street width, is no longer the optimal layout if the street width is increased to $6 \mathrm{~m}$ with the condition that the layout remains constant. In other words, while the optimal layout with a street width of $3 \mathrm{~m}$ is $\mathrm{B} 1$, which is surrounded by structures on three sides when the street width is increased to $6 \mathrm{~m}$, the corner parcel B6 surrounded by structures on two sides is determined to become the optimum layout. Therefore, it is concluded that street widths have a direct impact on the settlement patterns and affect annual expenses even if the parcel layout remains constant. In conceptual terms, street widths for the hot-dry climate zone have a direct impact on annual energy losses and gains. While, for hot dry climatic zones where the warmest season lasts longer than the coldest season, the B2 settlement layout, which is surrounded by the structures on all four sides and exposed to the shadow effect the most, is expected to be determined as the optimal layout with annual cooling energy gain, determining the B1 layout, which is surrounded by structures on three sides, as the optimal layout proves that energy-efficient design is an integrated design approach. In other words, in terms of bioclimatic based energy-efficient design, total annual energy costs optimization should be evaluated in the correct way.

Although it is seen that it is a priority to take measures to minimize cooling loads in hot dry climate zones, when the B1 settlement layout which is surrounded by three sides structures with optimal layout and B2 settlement layout which is surrounded by four sides structures with the least value regarding cooling costs are compared, the decrease in the annual cooling load value revealed the fact that it will 
not give optimal results concerning annual total energy expenses. In other words, the design concept that can keep the heating load at the optimal level, as well as the measures to minimize the cooling load in the residential settlements in Diyarbakır province, should be considered together. As a result of all these analyses, the structure form had a significant effect on the heating-cooling load values. Therefore, the central courtyard type was the optimum form. In the hot-dry climate zone, the shadow effect is an important climatic element. The street widths of the traditional city wall were taken as a reference. As a result of analyses, it was determined that the annual heating-cooling load values of all alternatives with a width of $3 \mathrm{~m}$ were less than $6 \mathrm{~m}$. As a result of this study, heating-cooling load values increased with increasing distance between structures. The results also differed in different building distances with the same layout. The optimum layout with a width of $3 \mathrm{~m}$ is B2, which is surrounded by structures on four sides, whereas the B1 with optimal layout is $6 \mathrm{~m}$ when the width of the street is $6 \mathrm{~m}$. Therefore, the construction distances have an effect on the annual heating-cooling load values depending on the settlement patterns. In conclusion, if the building distances switch, the annual heating-cooling load values change in proportion to the decrease in shadow effect even if the layout remains the same. In hot-dry climatic zones, energy load changes due to shade effect affect formal and settlement patterns.

\section{Discussion}

With this study, suitable building form and settlement pattern samples were determined for low-rise residential settlements to be built in this region and it is aimed at increasing the number of examples of climate-based residential settlements and to transfer traditional residential textures to today's designs.

Design solutions to minimize cooling costs are needed in the city of Diyarbakır, which is located in a hot and dry climate. In the first step of the design, with the environmental data, by looking at the building design parameters such as location, structure form, and direction of buildings with respect to each other, significant energy savings can be achieved by considering a bioclimatic design method which benefits from passive systems. As a result of analyses, shadow climate element has an important place in energy efficient structure design in hot-dry climate regions. In other words, when the street widths of 3 and $6 \mathrm{~m}$ are compared, it is concluded that the load values are less than $3 \mathrm{~m}$. The shadow effect can affect the annual energy loads not only on the scale of settlement, but also on the formal scale. Therefore, it is necessary to take design measures to create shadow effects in traditional courtyard type buildings which are examples of climate balanced design. If we adapt all these results to modern houses, we can achieve annual energy savings through the measures taken during the design phase.

In this context, the construction forms of traditional Diyarbakır houses were compared regarding energy costs. The optimum construction form was chosen in terms of heating-cooling load values. Then, the effect of shadow effect on energy loads in a hot dry climate region was examined by taking optimum building form as a reference, simulating different settlement layouts, and street widths of traditional Old Town texture. As a result, it was concluded that the same settlement layouts did not show the same thermal performance at different street widths ( 3 and $6 \mathrm{~m}$ ). While the width of the street is $3 \mathrm{~m}$, the settlement layout of $\mathrm{B} 1$, which is surrounded by structures on three sides with optimal layout, is expected to be the optimal layout when the width of the street is $6 \mathrm{~m}$ as well; the determination of B5, which is surrounded by structures on four sides, and B6, which is surrounded by structures on two sides as the optimal settlement units supported this opinion. According to result of the analysis, it was concluded that heating loads, besides the cooling loads in the hot-dry climate zone, have an effect on the total annual heat gains. In other words, in the case where the street width is $3 \mathrm{~m}$, while it is expected that the settlement layout B2 which is exposed to the most shadow effect among the settlements B1, B2, and B3 to be the optimal settlement unit, the fact that the settlement of B1 which is surrounded by buildings on three sides has less energy expenditure annually explains this situation. With this study, it is understood that design measures should be taken to minimize the cooling loads, especially in the hot-dry climate zone, as well as measures to 
optimize the heating loads. In addition, it was determined that energy losses and gains may be different if the width of the street is different in the same street layout. As a result of this study, it is possible to create a sustainable environment that consumes less energy by providing the integration of traditional building form and street texture to today's housing sector. If housing sector wants to save energy, traditional housing types and associated climate elements should be analyzed correctly. Moreover, a balanced design method should be developed with climate. It is emphasized that if the results obtained above are integrated into today's housing sector, more energy efficient structures will be produced, and a sustainable environment will be possible.

Author Contributions: Conceptualization, İ.A. and S.A.; methodology, İ.A. and S.A.; validation, İ.A.; formal analysis, I.A. and S.A.; investigation, İ.A. and S.A.; resources, S.A.; data curation, S.A.; writing-original draft preparation, İ.A., S.A., and L.S.G.; writing-review and editing, İ.A., S.A., and L.S.G.; visualization, S.A.; supervision, I.A. All authors have read and agreed to the published version of the manuscript.

Funding: This research received no external funding.

Conflicts of Interest: The authors declare no conflict of interest.

\section{References}

1. Du, K.; Calautit, J.; Wang, Z.; Wu, Y.; Liu, H. A review of the applications of phase change materials in cooling, heating and power generation in different temperature ranges. Appl. Energy 2018, 220, 242-273. [CrossRef]

2. Zhou, D.; Zhao, C.Y.; Tian, Y. Review on thermal energy storage with phase change materials (PCMs) in building applications. Appl. Energy 2012, 92, 593-605. [CrossRef]

3. Hatipoglu, H.K. Understanding social sustainability in housing form the case study "Wohnen Mit Uns" in Vienna and adaptibility to Turkey. Iconarp Int. J. Archit. Plan. 2017, 5, 87-109. [CrossRef]

4. Coma, J.; Chàfer, M.; Pérez, G.; Cabeza, L.F. How internal heat loads of buildings affect the effectiveness of vertical greenery systems? An experimental study. Renew. Energy 2019, 142. [CrossRef]

5. International Energy Outlook. 2016. Available online: https://www.eia.gov/outlooks/ieo/pdf/0484(2016).pdf (accessed on 13 October 2019).

6. Young, B.A.; Falzone, G.; Wei, Z.; Sant, G.; Pilon, L. Reduced-scale experiments to evaluate performance of composite building envelopes containing phase change materials. Constr. Build. Mater. 2018, 162, 584-595. [CrossRef]

7. Soflaei, F.; Shokouhian, M.; Abraveshdar, H.; Alipour, A. The impact of courtyard design variants on shading performance in hot-arid climates of Iran. Energy Build. 2017, 143, 71-83. [CrossRef]

8. Öz, K.; Özen Yavuz, A. Shape grammar analysis and comparison of the traditional and new urban textures in Sivrihisar, Eskişehir. Gazi Univ. J. Sci. Part B Art Humanit. Des. Plan. 2018, 6, 113-124.

9. Al-Azzawi, S. Indigenous courtyard houses: A comprehensive checklist for identifying, analysing and appraising their passive solar design characteristics Regions of the hot-dry climates. Renew. Energy 1994, 5, 1099-1123. [CrossRef]

10. Al Masri, N.; Abu Hijleh, B. Courtyard housing in midrise building: An environmental assessment in hot-arid climate. Renew. Sustain. Energy Rev. 2012, 16, 1892-1898. [CrossRef]

11. Sinou, M. Design and Thermal Diversity of Semi-Enclosed Spaces; Melrose Books: Ogun State, Nigeria, 2007.

12. Fathy, H. Natural Energy and Vernacular Architecture: Principles and Examples with Reference Hot-Arid Climates; University of Chicago Press: Chicago, IL, USA, 1986.

13. Berköz, E.; Küçükdoğu, M.; Yılmaz, Z.; Kocaaslan, G.; Ak, F. Energy Efficient Building and Settlement Design; TUBITAK-İNTAG 201; Research Report; Istanbul Technical University: Istanbul, Turkey, 1995.

14. Location of Diyarbakır. Available online: http://www.maphill.com/turkey/diyarbakir/location-maps/graymap/free/ (accessed on 18 October 2019).

15. Climate Data. Available online: https://en.climate-data.org/asia/turkey/diyarbak\%C4\%B1r/diyarbak\%C4\% B1r-285/\#climate-graph (accessed on 28 November 2019).

16. Sağıroğlu, Ö. Characteristics and construction techniques of Akseki Bucakalan Village Rural Dwellings. Int. J. Archit. Herit. 2017, 11, 433-455. [CrossRef] 
17. Location of Work Area. Available online: http://cografyaharita.com/haritalarim/41_diyarbakir_ili_haritasi.png (accessed on 20 November 2019).

18. Google Map. Available online: https://www.google.com/maps/search/suri\%C3\%A7i+\%C5\%9Filbe/@37. 9511218,40.2020973,12.22z (accessed on 27 November 2019).

19. Erginbaş, D. Diyarbakir Houses; Pulhan Press: Istanbul, Turkey, 1953.

20. Dalkılıç, N.; Bekleyen, A. Physical Traces of the Past Reflected in the Present: Traditional Diyarbakır Houses; Diyarbakır Governorship Publication: Diyarbakir, Turkey, 2011.

21. Akin, C.T.; Koca, C. Modelling transportation axes in Suriçi (Diyarbakir, Turkey) and determining their relationship to social areas allocated for public use. J. Asian Archit. Build. Eng. 2017, 16, 333-339. [CrossRef]

22. Kuban, D. Problems of Our Art History: Anatolian Turkish Art, Architecture, Essays on the City; Çağdaş Publication: Istanbul, Turkey, 1975.

23. Dağtekin, E.; Kakdaş Ateş, D.; Oğur, D. New housing design approaches in Diyarbakir street. J. Int. Soc. Res. 2018, 11. [CrossRef]

24. Google Earth. Available online: https://www.google.com/maps/@37.912263,40.2289968,14.14z (accessed on 9 November 2019).

25. Özyılmaz, H.; Sahil, S. The reflection of changing social structure: Diyarbakir Example. Megaron 2017, 12, 531-544.

26. Yıldırım, M. Shading in the outdoor enviroments of climate-friendly hot and dry historical streets: The passageways of Sanliurfa, Turkey. Environ. Impact Assess. Rev. 2020, 80, 106318. [CrossRef]

27. Oğuz, G.P.; Halifeoğlu, F.M. Construction tecniques and material protection problems in traditional Diyarbakir Houses. Dicle Univ. J. Eng. 2017, 8, 345-358.

28. Sözen, M.Ş.; Gedik, G.Z. Evaluation of traditional architecture in terms of building physics: Old Diyarbakır houses. Build. Environ. 2007, 42, 1810-1816. [CrossRef]

29. Gabriel, A. Diyarbakır City Walls; (Voyages archeolojique dans la Turquie Oriental); Gabriel, A., Translator; Diyarbakır Promotion, Culture and Solidarity Foundation: Diyarbakır, Turkey, 1940.

30. Bekleyen, A. Adapting the Old to New: Interpreting the Originality of Local Architecture in Contemporary Architecture; Construction Experiences in Historic Environment; Birsen Publication: Istanbul, Turkey, 2018.

31. Al-Hemiddi, N.A.; Al-Saud, K.A.M. The effect of a ventilated interior courtyard on the thermal performance of a house in a hot-arid region. Renew. Energy 2001, 24, 581-595. [CrossRef]

32. Muhaisen, A.S. Shading simulation of the courtyard form in different climatic regions. Build. Environ. 2006, 41, 1731-1741. [CrossRef]

33. Baran, M.; Yıldırım, M.; Yılmaz, A. Evaluation of ecological design strategies in traditional houses in Diyarbakir, Turkey. J. Clean. Prod. 2011, 19, 609-619. [CrossRef]

34. Tuncer, O.C. Diyarbakir Houses; Diyarbakir Metropolitan Municipality Culture and Art Press: Diyarbakir, Turkey, 1999.

35. Dalkılıç, N.; Aksulu, I. Traditional housing architecture in Diyarbakir. Gazi Univ. J. Art 2001, 2, 53-69.

36. Abdulac, S. Traditional Housing Design in the Arab Countries; Aga Khan Program for Islamic Architecture: Cambridge, MA, USA, 1982.

37. Ahani, F. Natural light in traditional architecture of Iran: Lessons to remember. Light Eng. Archit. Environ. 2011, 121, 25-36.

38. Foruzanmehr, A. Summer-time thermal comfort in vernacular earth dwellings in Yazd, Iran. Int. J. Sustain. Des. 2012, 2, 46-63. [CrossRef]

39. Herdeg, K. Formal Structure in Islamic Architecture of Iran and Turkistan; Rizzoli International Publication: New York, NY, USA, 1990.

40. Khajehzadeh, I.; Vale, B.; Yavari, F. A comparison of the traditional use of court houses in two cities. Int. J. Sustain. Built Environ. 2016, 5, 470-483. [CrossRef]

41. Saljoughinejad, S.; Sharifabad, S. Classification of climatic strategies, used in Iranian vernacular residences based on spatial constituent elements. Build. Environ. 2015, 92, 475-493. [CrossRef]

42. Sözen, İ; Oral, G.K. Outdoor thermal comfort in urban canyon and courtyard in hot arid climate: A parametric study based on the vernacular settlement of Mardin. Sustain. Cities Soc. 2019, 48, 101398. [CrossRef]

43. Zhang, L. Simulation analysis of built environment based on design builder software. Appl. Mech. Mater. 2014, 580, 3134-3137. [CrossRef] 
44. Riahi Zaniani, J.; Taghipour Ghahfarokhi, S.; Jahangiri, M.; Alidadi Shamsabadi, A. Design and optimization of heating, cooling and lightening systems for a residential villa at Saman city, Iran. J. Eng. Des. Technol. 2019, 17, 41-52. [CrossRef]

45. Design Builder Software Version 5.03.007, Designbuilder Software Limited, Clarendon Court 1st Floor 54/56 London Rd Stroud, Gloucestershire GL5 2AD, UK. 2017.

46. Rezaei, A.A.; Yousefi, T. Free convection heat transfer from a horizontal fin attached cylinder between confined nearly adiabatic walls. Exp. Therm. Fluid Sci. 2010, 34, 177-182. [CrossRef]

(C) 2020 by the authors. Licensee MDPI, Basel, Switzerland. This article is an open access article distributed under the terms and conditions of the Creative Commons Attribution (CC BY) license (http://creativecommons.org/licenses/by/4.0/). 